\title{
Opening doors: a review of the Protozoa and Insecta taxa published under Wellcome Trust funding at Instituto Evandro Chagas, Belém, Pará State, Brazil
}

\author{
Abrindo portas: uma revisão dos táxons de Protozoa e Insecta publicados, sob o \\ financiamento da Welcome Trust, no Instituto Evandro Chagas, Belém, Pará, Brasil
}

Jeffrey Jon Shaw

' Universidade de São Paulo, Departamento de Parasitologia, São Paulo, São Paulo, Brasil

\begin{abstract}
Wellcome Trust and Instituto Evandro Chagas (IEC) joined research efforts during more than 40 years, and many publications have been made about the scientific contributions with the content of this partnership. The aim of the present historical article is to list the new species of Protozoa and Insecta that were named during the presence of Welcome Trust funding at IEC and to briefly mention how their discovery influenced future research and to show how they relate to present trends in the different areas. The result was a total of 119 new species named in conjunction with their hosts and authors, and five that were transferred (comb. nov.); Ralph Lainson authored/co-authored 108, Jeffrey Shaw 60 new species, 56 by Lainson and Shaw, and seven by other colleague authors. Most of the species were discovered in Brazil. The description of these new species has provided a clearer understanding of the taxonomic groups to which they belong and how some are transmitted to man with their resultant pathologies and treatments. And many scientific doors were opened showing the variety of protozoal parasites in Amazonian vertebrates.
\end{abstract}

Keywords: Protozoa; Parasites; Insecta; Parasite-Host Relation; Taxonomy.

\section{RESUMO}

A Wellcome Trust e o Instituto Evandro Chagas (IEC) aliaram esforços pela pesquisa durante mais de 40 anos, e muitas publicações foram feitas sobre as contribuições científicas resultantes dessa parceria. $\bigcirc$ objetivo deste artigo histórico é listar as novas espécies de Protozoa e Insecta que foram nomeadas durante a presença do financiamento da Wellcome Trust no IEC, e mencionar resumidamente como a descoberta das mesmas influenciou futuras pesquisas e mostrar como se relacionam com as atuais tendências nas diferentes áreas. O resultado foram 119 novas espécies nomeadas juntamente com seus autores e hospedeiros e cinco que foram transferidas (comb. nov.); Ralph Lainson foi autor/coautor de 108, Jeffrey Shaw, de 60, Lainson e Shaw, de 56, e outros autores colegas, de sete. A maioria das espécies foram descobertas no Brasil. A descrição dessas novas espécies proporcionou uma compreensão mais clara dos grupos taxonômicos aos quais elas pertencem e como algumas são transmitidas ao homem com suas patologias e tratamentos resultantes. $E$ muitas portas científicas foram abertas, mostrando a variedade de parasitas protozoários nos vertebrados da Amazônia.

Palavras-chave: Protozoa; Parasitos; Insecta; Interações Hospedeiro-Parasita; Taxonomia. 


\section{INTRODUCTION}

An article ${ }^{1}$ on Wellcome Trust funded research at Instituto Evandro Chagas, in Pará State, Brazil, did not give details of the new organisms that were discovered. A total of 119 new species were named and, due to taxonomic revisions, five species named previously by other authors were transferred (comb. nov.) to newly created genera. These taxa are listed in table 1 together with their hosts and authors. The aim of the present article is to briefly mention how their discovery influenced future research and to show how they relate to present trends in the different areas.

Ralph Lainson was supported for the longest period and his contributions were dominant, being an author/co-author of 108 new species and five new combinations. Jeffrey Shaw authored/co-authored 60 new species and two new combinations. One hundred and one of these new species were discovered in Brazil and two names were given to Leishmania found in Panama. The descriptions of 13 published individually by Ralph Lainson (10) and Jeffrey Shaw (three) were of material that they had collected while respectively working in Belize and Central America.

\section{SPECIES OF PROTOZOA}

\section{PROTOZOA: EUCOCCIDIIDA \& MICROSPORIDIA}

The taxonomic ranks (family, genus, and subgenus) that were created for some of the species are not listed in table 1 and are as follows: the haemosporidian genus Saurocytozoon Lainson \& Shaw, 1969² ; the haemosporidian family Garnidae Lainson, Landau \& Shaw, $1971^{3}$ containing the genera Garnia Lainson, Landau \& Shaw, 1971, Fallisia Lainson, Landau \& Shaw, 19744, and Progarnia Lainson, 19955; two hemogregarine genera Cyrilia Lainson, $1981^{6}$ and Hemolivia Petit, Landau, Baccam \& Lainson, 19907; and the microsporidian genus Alloglugea Paperna \& Lainson, $1995^{\circ}$. A simple question is why were they found? All are from cold-blooded vertebrates and the majority is from lizards. While searching for lizard Leishmania that to this date have never been found in the Americas, a wealth of parasites was discovered in different blood cells, opening new research areas. However, besides this, it was obvious that an enormous number of parasites was waiting to be discovered. Thus, any available animal was examined for parasites, irrespective of it being a potential reservoir of a human disease.

Their discoveries stimulated others to look for them around the world. Garnia is only known in the Western Hemisphere; Fallisia species have been recorded in the Americas, South East Asia, and Australasia; and Saurocytozoon occurs in both North and South America and in Asia9. Molecular methods are now showing possible evolutionary pathways that reflect the above distributions. The 60 Eimeridae species listed in table 1 were found in either warm or cold blooded vertebrates. A recent paper ${ }^{10}$ showed that species of Cyclospora, Eimeria, and Isospora from warm blooded vertebrates form a well-supported clade, but organisms identified as Eimeria or Isospora species from cold-blooded vertebrates and marsupials do not fall within this group, suggesting that these are polyphyletic genera. For example, based on $18 \mathrm{~S}$ rRNA sequences ${ }^{10}$, two Eimeria species, one from a snake and the other from an anuran, were phylogenetically closer to European Schellackia species within the family Schellackiidae. These observations clearly indicate that future revisions will be required to resolve the polyphyletic genera.

Six species of Sarcocystis were described based on distinctive cyst wall morphology. Except for one, their definitive hosts are unknown. The sexual cycle of Sarcocystis ameivamastigodryasi Lainson \& Paperna, $2000^{11}$ of the teiid lizard, Ameiva ameiva occurs in the intestine of the colubrid snake, Mastigodryas bifossatus. The oocysts are like those of Isospora species having two sporocysts that contain four sporozoites. In the case of the teiid parasite, the oocyst wall ruptures inside the snake's intestine so mature sporocysts are liberated in the faeces. The cystic stage normally occurs in herbivores and the sexual stage in carnivores ranging from canids, corvid birds to snakes. It is possible that some Isospora species could in fact be Sarcocystis species.

\section{PROTOZOA: KINETOPLASTIDA}

Given the medical importance of Leishmania species, it is not surprising that the most well-known taxa and taxonomic rank, established in Belém, Pará State, under Wellcome Trust funding, belong to this genus. The creation of the subgenus Leishmania (Viannia) Lainson \& Shaw, $1987^{12}$ was a fundamental step forward in understanding the disease known as leishmaniasis and its phylogeny. Parasites belonging to this subgenus are only found in the Americas, while those of the subgenus Leishmania (Leishmania) are found in the Old World and the Americas. Three previously named organisms, L. braziliensis, L. guyanensis, and L. peruviana were assigned to this subgenus and eight other species were described (Table 1). All but two of these belong to the subgenus L. (Viannia). One of these, L. (L.) amazonensis Lainson \& Shaw, 1972 ${ }^{13}$, grows profusely in culture and readily infects a range of laboratory animals, producing in hamsters a pathology like diffuse cutaneous leishmaniasis. Because of these attributes this parasite is used extensively in immunological and chemotherapeutic studies. Molecular methods ${ }^{14}$ have shown that the subgenus L. (Viannia) separated from the basal stock some 80 MYA while the subgenus L. (Leishmania) separation was later being around 50 MYA. There are distinct differences between the immunological response and pathology of the two subgenera in man. Somewhere along the evolutionary line, the subgenus L. (Leishmania) seems to have opted to depress the cell mediated response, while the subgenus L. (Viannia) opted to stimulate it. Perhaps this was due to the very different mammalian hosts in which the two subgenera evolved, one possible being rodents and the other Xenarthra. Today we see this reflected in the extreme immunological differences between diffuse cutaneous leishmaniasis caused by L. (L.) amazonensis and mucocutaneous by L. (V.) braziliensis ${ }^{15}$. 
Table 1 - Taxa described under funding of the Wellcome Trust by Ralph Lainson, Jeffrey Shaw and their colleagues while working at the Instituto Evandro Chagas, Belém, Pará, Brazil

\begin{tabular}{|c|c|}
\hline Protozoa & Host \\
\hline \multicolumn{2}{|l|}{ Eucoccidiida: Haemosporida: Plasmodiidae } \\
\hline Plasmodium vacuolatum Lainson, Shaw \& Landau, 1975 & Lizard \\
\hline Plasmodium neusticuri Lainson \& Paperna, 1996 & Lizard \\
\hline Plasmodium kentropyxi Lainson, Landau \& Paperna, 2001 & Lizard \\
\hline Plasmodium carmelinoi Lainson, Franco \& Matta, 2010 & Lizard \\
\hline \multicolumn{2}{|l|}{ Eucoccidiida: Haemosporida: Leucocyłozoidae } \\
\hline Saurocytozoan tupinambi Lainson \& Shaw, 1969 & Lizard \\
\hline Saurocyłozoan mabuyi Lainson, Landau \& Shaw, 1974 & Lizard \\
\hline \multicolumn{2}{|l|}{ Eucoccidiida: Haemosporida: Haemoproteidae } \\
\hline Polychromophilus deanei Garnham, Lainson \& Shaw, 1971 & Bat \\
\hline Haemoproteus peltocephali Lainson \& Naiff, 1998 & Lizard \\
\hline Haemoproteus geochelonis Lainson \& Naiff, 1998 & Lizard \\
\hline \multicolumn{2}{|l|}{ Eucoccidiida: Haemosporida: Garniidae } \\
\hline Garnia gonatodi (Telford, 1970) Lainson, Landau \& Shaw, 197l, comb. nov. & Lizard \\
\hline Garnia telfordi Lainson, Landau \& Shaw, 1971 & Lizard \\
\hline Garnia utingensis Lainson, Landau \& Shaw, 1971 & Lizard \\
\hline Garnia multiformis Lainson, Shaw \& Landau, 1975 & Lizard \\
\hline Garnia uranoscodoni Lainson, Shaw \& Landau, 1975 & Lizard \\
\hline Garnia morula (Telford, 1970) Lainson, Landau \& Shaw, 1971, comb. nov. & Lizard \\
\hline Garnia karyolytica Lainson \& Naiff, 1999 & Lizard \\
\hline Fallisia effusa Lainson, Landau \& Shaw, 1974 & Lizard \\
\hline Fallisia modesta Lainson, Landau \& Shaw, 1974 & Lizard \\
\hline Fallisia audaciosa Lainson, Shaw \& Landau, 1975 & Lizard \\
\hline Fallisia simplex Lainson, Shaw \& Landau, 1975 & Lizard \\
\hline Progarnia archosauriae Lainson, 1995 & Lizard \\
\hline \multicolumn{2}{|l|}{ Eucoccidiida: Adeleina: Haemogregarinidae } \\
\hline \multicolumn{2}{|l|}{ Cyrilia lignieresi (Laveran, 1906) Lainson, 1992, comb. nov. } \\
\hline $\begin{array}{l}\text { (Syns Haemogregarina lignieresi Laveran, 1906; } \\
\text { H. gomesi Neiva \& Pinto, 1926; } \\
\text { Cyrilia gomesi Lainson, 1981) }\end{array}$ & Fish \\
\hline Hemolivia stellata Petit, Landau, Baccam \& Lainson, 1990 & Anuran \\
\hline \multicolumn{2}{|l|}{ Eucoccidiida: Eimeriina: Lankesterellidae } \\
\hline Lankesterella petiti Lainson \& Paperna, 1995 & Anuran \\
\hline \multicolumn{2}{|l|}{ Eucoccidiida: Eimeriina: Schellackiidae } \\
\hline Schellackia landauae Lainson, Shaw \& Ward, 1976 & Lizard \\
\hline \multicolumn{2}{|l|}{ Eucoccidiida: Eimeriina: Eimeridae } \\
\hline Tyzzeria boae Lainson \& Paperna, 1994 & Snake \\
\hline Cyclospora niniae Lainson, 1965 & Snake \\
\hline Cyclospora schneideri Lainson, 2005 & Snake \\
\hline Caryospora pseustesi Lainson, Nascimento \& Shaw, 1991 & Snake \\
\hline Caryospora micruri Lainson, Nascimento \& Shaw, 1991 & Snake \\
\hline Caryospora constanciae Lainson, Nascimento \& Shaw, 1991 & Snake \\
\hline Caryospora paraensis Lainson, Nascimento \& Shaw, 1991 & Snake \\
\hline Caryospora carajasensis Lainson, Nascimento \& Shaw, 1991 & Snake \\
\hline Caryospora epicratesi Lainson, Nascimento \& Shaw, 1991 & Snake \\
\hline Isospora albicolis Lainson \& Shaw, 1989 & Bird \\
\hline Isospora wilkiei Lainson, 1968 & Crocodile \\
\hline Isospora basilisci Lainson, 1968 & Lizard \\
\hline Isospora tucurviensis Lainson \& Shaw, 1989 & Bird \\
\hline
\end{tabular}


Table 1 - Taxa described under funding of the Wellcome Trust by Ralph Lainson, Jeffrey Shaw and their colleagues while working at the Instituto Evandro Chagas, Belém, Pará, Brazil

\begin{tabular}{|c|c|}
\hline Protozoa & Host \\
\hline Isospora saimiri Lainson \& Shaw, 1989 & Mammal \\
\hline Isospora cacici Lainson, 1994 & Bird \\
\hline Isospora thraupis Lainson, 1994 & Bird \\
\hline Isospora capanemaensis Lainson, 2003 & Mammal \\
\hline Isospora rodriguesae Lainson, Da Silva, Franco \& De Souza, 2008 & Chelonia \\
\hline Eimeria orthogeomyos Lainson, 1968 & Mammal \\
\hline Eimeria tamanduae Lainson, 1968 & Mammal \\
\hline Eimeria rhynchonycteridis Lainson, 1968 & Mammal \\
\hline Eimeria pseudemydis Lainson, 1968 & Turtle \\
\hline Eimeria bothrops Lainson, 1968 & Snake \\
\hline Eimeria ameivae Lainson, 1968 & Lizard \\
\hline Eimeria crocodyli Lainson, 1968 & Crocodile \\
\hline Eimeria poti Lainson, 1968 & Mammal \\
\hline Eimeria micruri Lainson \& Shaw, 1973 & Snake \\
\hline Eimeria liophi Lainson \& Shaw, 1973 & Snake \\
\hline Eimeria leimadophi Lainson \& Shaw, 1973 & Snake \\
\hline Eimeria cyclopei Lainson \& Shaw, 1982 & Mammal \\
\hline Eimeria choloepi Lainson \& Shaw, 1982 & Mammal \\
\hline Eimeria trichechi Lainson, Naiff, Best \& Shaw, 1983 & Mammal \\
\hline Eimeria philanderi Lainson \& Shaw, 1989 & Mammal \\
\hline Eimeria caluromydis Lainson \& Shaw, 1989 & Mammal \\
\hline Eimeria vitellini Lainson, Costa \& Shaw, 1990 & Bird \\
\hline Eimeria corticulata Lainson \& Shaw, 1990 & Mammal \\
\hline Eimeria zygodontomyis Lainson \& Shaw, 1990 & Mammal \\
\hline Eimeria lagunculata Lainson, Costa \& Shaw, 1990 & Chelonia \\
\hline Eimeria mammiformis Lainson, Costa \& Shaw, 1990 & Chelonia \\
\hline Eimeria podocnemis Lainson, Costa \& Shaw, 1990 & Chelonia \\
\hline Eimeria carinii Lainson, Costa \& Shaw, 1990 & Chelonia \\
\hline Eimeria marajoensis Lainson \& Shaw, 1991 & Mammal \\
\hline Eimeria porphyrulae Lainson, 1994 & Bird \\
\hline Eimeria crypturelli Lainson, 1994 & Bird \\
\hline Eimeria bufomarini Paperna \& Lainson, 1995 & Anuran \\
\hline Eimeria peltocephali Lainson \& Naiff, 1998 & Turtle \\
\hline Eimeria molossi Lainson \& Naiff, 1998 & Bat \\
\hline Eimeria bragancaensis Lainson \& Naiff, 2000 & Bat \\
\hline Eimeria carmelinoi Lainson, 2002 & Lizard \\
\hline Eimeria damnosa Lainson, Brigido \& Silveira, 2005 & Mammal \\
\hline Eimeria lepidosirenis Lainson \& Ribeiro, 2006 & Fish \\
\hline Eimeria amazonensis Lainson, Da Silva, Franco \& De Souza, 2008 & Chelonia \\
\hline Eimeria carbonaria Lainson, Da Silva, Franco, \& De Souza, 2008 & Chelonia \\
\hline Eimeria carajasensis Lainson, Da Silva, Franco \& De Souza, 2008 & Chelonia \\
\hline Eimeria wellcomei Lainson, Da Silva, Franco \& De Souza, 2008 & Chelonia \\
\hline Acroeimeria paraensis Lainson, 2002 & Lizard \\
\hline Acroeimeria cnemidophori (Carini, 1941) Lainson, 2002, comb. nov. & Mammal \\
\hline Choleoeimeria rochalima (Carini \& Pinto, 1926) Lainson \& Paperna, 1999, comb. nov. & Lizard \\
\hline Choleoeimeria carinii Lainson \& Paperna, 1999 & Lizard \\
\hline Choleoeimeria amphisbaenae Lainson, 2003 & Lizard \\
\hline \multicolumn{2}{|l|}{ Eucoccidiida: Eimeriina: Sarcocystidae } \\
\hline Sarcocystis kinosterni Lainson \& Shaw, 1972 & Mammal \\
\hline Sarcocystis azevedoi Shaw \& Lainson, 1969 & Mammal \\
\hline Sarcocystis marmosae Shaw \& Lainson, 1969 & Mammal \\
\hline Sarcocystis oryzomyos Shaw \& Lainson, 1969 & Mammal \\
\hline Sarcocystis proechimyos Shaw \& Lainson 1969 & Mammal \\
\hline Sarcocystis ameivamastigodryasi Lainson \& Paperna, 2000 & Lizard/Snake \\
\hline
\end{tabular}


Table 1 - Taxa described under funding of the Wellcome Trust by Ralph Lainson, Jeffrey Shaw and their colleagues while working at the Instituto Evandro Chagas, Belém, Pará, Brazil

\begin{tabular}{|c|c|}
\hline Protozoa & Host \\
\hline \multicolumn{2}{|l|}{ Piroplasmida: Theileriidae } \\
\hline Theileria electrophori Lainson, 2007 & Fish \\
\hline \multicolumn{2}{|l|}{ Microspora: Glugeidae } \\
\hline Alloglugea bufonis Paperna \& Lainson, 1995 & Anuran \\
\hline \multicolumn{2}{|l|}{ Kinetoplastida: Trypanosomatidae } \\
\hline Endotrypanum monterogeii Shaw, 1969 & Mammal \\
\hline Leishmania (Leishmania) amazonensis Lainson \& Shaw, 1972 & Mammal* \\
\hline Leishmania (Viannia) panamensis Lainson \& Shaw, 1972 & Mammal* $^{*}$ \\
\hline Leishmania (Leishmania) aristidesi Lainson \& Shaw, 1979 & Mammal \\
\hline Leishmania (Viannia) lainsoni Silveira, Shaw, Braga \& Ishikawa, 1987 & Mammal* $^{*}$ \\
\hline Leishmania (Viannia) naiffi Lainson \& Shaw, 1989 & Mammal* \\
\hline Leishmania (Viannia) shawi Lainson, Braga, de Souza, Póvoa \& Ishikawa, 1989 & Mammal* $^{*}$ \\
\hline Leishmania (Viannia) lindenbergi Silveira, Ishikawa, de Souza \& Lainson, 2002 & Mammal* $^{*}$ \\
\hline Leishmania (Viannia) utingensis Braga, Lainson, Ishikawa \& Shaw, 2003 & Mammal \\
\hline Porcisia deanei (Lainson \& Shaw, 1977) Espinosa et al., 2018 & Mammal \\
\hline Trypanosoma leuwenhoeki Shaw, 1969 & Mammal \\
\hline Trypanosoma preguici Shaw, 1969 & Mammal \\
\hline Trypanosoma plicae Lainson, Shaw \& Landau, 1975 & Lizard \\
\hline Trypanosoma cecili Lainson, 1977 & Crocodile \\
\hline Trypanosoma (Megatrypanum) saloboense Lainson, Da Silva \& Franco, 2008 & Mammal \\
\hline
\end{tabular}

Insecta

Diptera: Psychodidae: Phlebotominae

Bruptomyia orlandoi Fraiha, Shaw \& Lainson, 1970

Psychodopygus wellcomei Fraiha, Shaw \& Lainson, $1971^{\dagger}$

Psychodopygus lainsoni Fraiha \& Ward, 1974

Nyssomyia umbratilis (Ward \& Fraiha, 1977) Galati, 2003‡

Psychodopygus Ilanosmartinsi Fraiha \& Ward, 1980'

Nyssomyia shawi (Fraiha, Ward \& Ready, 1981) Galati, 2003†

Nyssomyia richardwardi (Ready \& Fraiha, 1981) Galati, 2003

Trichopygomyia ratcliffei (Arias, Ready \& Freitas, 1983) Galati, 2003

Psychodopygus leonidasdeanei Fraiha, Ryan, Ward, Lainson \& Shaw, 1986

Evandromyia carmelinoi (Ryan, Fraiha, Lainson \& Shaw, 1986) Galati, 2003

Trichopygomyia readyi (Ryan, 1986) Galati, 2003

* Infections found in man; ${ }^{\dagger}$ Found infected with Leishmania (Viannia) braziliensis; ${ }^{\ddagger}$ Found infected with Leishmania (Viannia) guyanensis.

Leishmania hertigi deanei Lainson \& Shaw 197716, later raised to specific status by Lainson and Shaw ${ }^{12}$ in 1987, is very different from all other Leishmania. The amastigotes are very large and do not appear to be intracellular. Latterly studies have shown that it is phylogenetically outside the genus Leishmania being closer to Endotrypanum. This led to the creation of the genus Porcisia Shaw, Camargo \& Teixeira $2016^{17}$ to accommodate it and the Panamanian porcupine parasite, P. hertigi.

Great advances in our understanding of the taxonomy of Trypanosoma (Schizotrypanum) cruzi were made by Miles et al. ${ }^{18}$ while working at the Instituto Evandro Chagas that confirmed three genetically distinct lineages that were denoted as Type I, II \& III. In the opinion of the author these represent distinct species but have never been named so they do not appear in table 1. Subsequently these lineages have been shown to be distinct by with different molecular markers.

\section{SPECIES OF INSECTS}

\section{INSECTA: DIPTERA: PSYCHODIDAE: PHLEBOTOMINAE}

Unravelling the epidemiologies of the different Leishmania species inevitable led to the discovery of new phlebotomine species. It also showed how the epidemiological importance of different groups varies in different biomes. The discovery of Psychodopygus wellcomei Fraiha, Shaw \& Lainson $1971^{19}$ was the first indication of the vectorial importance of this genus for L. (Viannia) species in Amazonia. Six Psychodopygus species are associated with $L$. (V.) braziliensis and five with $L$. (V.) naiffi20. It is the predominant genus in south of the Amazon River extending to virgin Atlantic rain forest. In north of the river, L. (V.) guyanensis, transmitted by $N$. umbratilis, is the dominant leishmania in man. The number of Nyssomyia sand flies is significantly greater in this biome, but there is no significant difference in the variety of species of Nyssomyia and Psychodopygus ${ }^{21}$. 
Continuous environmental variations related to global warming and man's activities modulate the sand fly fauna. Understanding and documenting this is the challenge.

\section{CONCLUSION}

Unforeseen benefits have resulted from the description of the species that form the subject of this paper. They range from a clearer understanding of the taxonomic groups to which they belong to how some are transmitted to man with resultant contrasting pathologies and treatments. For example, in 1965 it was accepted that Leishmania braziliensis was the etiological agent of all forms of cutaneous leishmaniasis in Brazil. Studies of the parasites from wild animals, man and sand flies showed that this was wrong. Many scientific doors were opened, giving just a glimpse to the amazing variety of protozoal parasites that occur in Amazonian vertebrates.

\section{REFERENCES}

1 Shaw JJ. A partnership that worked: the Wellcome Trust and the Instituto Evandro Chagas and beyond. Rev Pan-Amaz Saude. 2016;7(esp):23-42.

2 Lainson R, Shaw JJ. A new haemosporidian of lizards, Saurocytozoon tupinambi gen.nov., sp.nov., in Tupinambus nigropunctatus (Teiidae). Parasitology. 1969 Feb;59(1):159-62.

3 Lainson R, Landau I, Shaw JJ. On a new family of non-pigmented parasites in the blood of reptiles: Garniidae fam. nov., (Coccidiida: Haemosporidiidea). Some species of the new genus Garnia. Int J Parasitol. 1971 Dec;1971(3-4):245-50.

4 Lainson R, Landau I, Shaw JJ. Further parasites of the family Garniidae (Coccidiida: Haemosporidiidea) in Brazilian lizards. Fallisia effusa gen.nov., sp.nov. and Fallisia modesta gen. nov., sp.nov. Parasitology. 1974 Apr;68(2):117-25.

5 Lainson R. Progarnia archosauriae nov. gen., nov. sp. (Haemosporina: Garniidae), a blood parasite of Caiman crocodilus crocodilus (Archosauria: Crocodilia), and comments on the evolution of reptilian and avian haemosporines. Parasitology. 1995 Jun;1 10(5):513-9.

6 Lainson R. On Cyrilia gomesi (Neiva \& Pinto, 1926) gen.nov. (Haemogregarinidae) and Truypanosoma bourouli Neiva \& Pinto, in the fish Synbranchus marmoratus: simultaneous transmission by the leech Haementeria lutzi. In: Canning EU, editor. Parasitological topics: a presentation volume to P.C.C. Garnham, F.R.S. on the occasion of his 80th birthday. Kansas: Society of Protozoologists; 1981. p. 150-8.

7 Petit G, Landau I, Baccam D, Lainson R. Description et cycle biologique d'Hemolivia stellata n. g., n. sp., hémogrégarine de crapauds brésiliens. Ann Parasitol Hum Comp. 1990 Jan;65(1):3-15.

8 Paperna I, Lainson R. Alloglugea bufonis nov. gen., nov. sp. (Microsporea: Glugeidae), a microsporidian of Bufo marinus tadpoles and metamorphosing toads (Amphibia: Anura) from Amazonian Brazil. Dis Aquat Org. 1995 Sep;23(1):7-16.
9 Telford SR. Plasmodia of reptiles. In: Kreier JP, editor. Parasitic protozoa. 2nd ed. New York: Academic Press; 1994. Chapter 1; p. 1-71.

10 Megía-Palma R, Martínez J, Paranipe D, D'Amico V, Aguilar R, Palacios MG, et al. Phylogenetic analyses reveal that Schellackia parasites (Apicomplexa) detected in American lizards are closely related to the genus Lankesterella: is the range of Schellackia restricted to the Old World? Parasit Vectors. 2017 Oct;10(1):470.

11 Lainson R, Paperna I. The life-cycle and ultrastructure of Sarcocystis ameivamastigodryasi n. sp., in the lizard Ameiva ameiva (Teiidae) and the snake Mastigodryas bifossatus (Colubridae). Parasite. 2000 Dec;7(4):263-74.

12 Lainson R, Shaw JJ. Evolution, classification and geographical distribution. In: Peters W, Killick-Kendrick R, editors. The leishmaniases in biology and medicine. Vol. 1, Biology and epidemiology. London: Academic Press; 1987. p. 1-120.

13 Lainson R, Shaw JJ. Leishmaniasis of the New World: taxonomic problems. Br Med Bull. 1972 Jan;28(1):44-8.

14 Harkins KM, Schwartz RS, Cartwright RA, Stone AC. Phylogenomic reconstruction supports supercontinent origins for Leishmania. Infect Genet Evol. 2016 Mar;38(1):101-9.

15 Silveira FT. What makes mucosal and anergic diffuse cutaneous leishmaniases so clinically and immunopathogically different? A review in Brazil. Trans R Soc Trop Med Hyg. 2019 May. pii: trz037.

16 Lainson R, Shaw JJ. Leishmanias of neotropical porcupines: Leishmania hertigi deanei nov. subsp. Acta Amaz. 1977 Mar;7(1):51-7.

17 Espinosa OA, Serrano MG, Camargo EP, Teixeira MMG, Shaw JJ. An appraisal of the taxonomy and nomenclature of trypanosomatids presently classified as Leishmania and Endotrypanum. Parasitology. 2018 Apr; 145(4):430-42. 
18 Miles MA, Souza A, Povoa M, Shaw JJ, Lainson R, Toye PJ. Isozymic heterogeneity of Trypanosoma cruzi in the first autochthonous patients with Chagas' disease in Amazonian Brazil. Nature. 1978 Apr;272(5656):819-21.

19 Fraiha H, Shaw JJ, Lainson R. Phlebotominae brasileiros: II - Psychodopygus wellcomei, nova espécie antropófila de flebótomo do grupo squamiventris, do Sul Estado do Pará, Brasil (Diptera, Psychodidae). Mem Inst Oswaldo Cruz. $1971 ; 69(3): 489-500$.
20 Dvorak V, Shaw J, Volf Pjenn. 3 Parasite biology: the vectors. Bruschi F, Gradoni L, editors. The leishmaniases: old neglected tropical diseases. [place unknown]: Springer International Publishing; 2018. p. $31-77$.

21 Souza AAA, Barata IR, Silva MGS, Lima JAN, Jennings YLL, Ishikawa EAY, et al. Natural Leishmania (Viannia) infections of phlebotomines (Diptera: Psychodidae) indicate classical and alternative transmission cycles of American cutaneous leishmaniasis in the Guiana Shield, Brazil. Parasite. 2017 May;24:13. 